

\title{
THE EFFICIENCY OF SUGARCANE (Saccharum officinarum) FARMS USING THE DEA (DATA ENVELOPMENT ANALYSIS) APPROACH IN PURWOREJO REGENCY
}

\author{
Widyadhari Febriani Setyaningrum", Titik Ekowati, and Budi Adi Kristanto \\ Agribusiness, Faculty of Animal and Agricultural Sciences, Diponegoro University, \\ Semarang, Indonesia \\ Correspondence email: febri_ani03@yahoo.co.id
}

Submitted 27 February 2020; Accepted 10 August 2020

\begin{abstract}
ABSTRAK
Penelitian ini bertujuan mengetahui tingkat efisiensi teknis usahatani tebu di Kabupaten Purworejo. Metode penelitian menggunakan analisis DEA (Data Envelopment Analysis) dengan asumsi input oriented digunakan untuk mengukur skor efisiensi dari masing-masing usahatani yang diamati. Hasil penelitian menunjukkan bahwa sebagian besar usahatani tebu di Kabupaten Purworejo masuk dalam kategori inefisien. Berdasarkan perhitungan DEA-CRS terdapat 11 usahatani tebu (19,3\%) yang telah beroperasi secara efisien dan 46 usahatani tebu (80,7\%) belum beroperasi secara efisien (inefisien). Perhitungan efisiensi menggunakan asumsi Variable Return To Scale (VRS) menghasilkan nilai rata-rata efisiensi 0,937 . Efisiensi dicapai oleh 21 orang $(36,84 \%)$ sedangkan sisanya sebanyak 36 orang $(63,16)$ masih belum mencapai efisiensi.
\end{abstract}

Kata Kunci: analisis SWOT, domba, kelompok tani ternak, strategi pengembangan

\begin{abstract}
The research was purposed to know the technical efficiency level of sugarcane farming in Purworejo regency. The research method used DEA (Data Envelopment Analysis) with the inputoriented assumption to measure the efficiency score from each observed farming. The result of the research showed most of the sugarcane farming in Purworejo regency was categorized as inefficient. According to DEA-CRS calculation, there were 11 sugarcane farming 19,3\%) who have operated efficiently and 46 sugarcane farming (80,7\%) have not operated efficiently yet (inefficient). The efficiency calculation using Variable Return To Scale (VRS) assumption resulted in an average efficiency value of 0.937. Efficiency was reached by 21 people (36.84\%) while the other 36 people $(63.16 \%)$ still have not reached efficiency yet.
\end{abstract}

Keywords: DEA, efficiency, sugar cane

\section{INTRODUCTION}

The majority of sugarcane farming in Indonesia is cultivated by the people, with the contribution of Smallholder Sugarcane Plantations in 2017 of $55.41 \%$ (Statistics Indonesia, 2017). Central Java, as the third sugarcane producing province in Indonesia, has an area of 60.444 .03 ha of sugarcane. Sugarcane in Central Java is spread across almost all regencies, one of which is Purworejo Regency. In 2017, the area of sugar cane in Purworejo Regency was 411.06 ha, it is decreased by 246.17 ha from the previous year which was 657.23 ha. One of the obstacles experienced in sugarcane farming activities, especially in Purworejo Regency is the low productivity of sugarcane. Fitriani and Irawati (2013) revealed that the average productivity of sugar crystal was 5.82 
tons/ha. This shows that the condition of the sugarcane plant is still below the condition of its potential production which can reach 8 tons/ha. Asyarif (2018) in his research states that sugarcane productivity which tends to decline indicates inefficiency at the level of the farmer's sugarcane farming. The efficiency of sugarcane farming is strongly related to the use of inappropriate production factors. Inefficiencies in the use of production factors can be influenced by the use of excessive inputs or the use of inappropriate inputs and thereby they only increase costs without increasing production. This study aimed to analyze the efficiency level of the use of production factors consisting of land area, ZA fertilizer, NPK fertilizer, and organic fertilizer, labor, and pest attacks.

Efficiency can be defined as an action that can minimize waste or loss of resources in carrying out an activity or in producing something. Efficiency can also be interpreted as an effort to use the smallest possible input to get the maximum production (Soekartawi, 2010). In short, according to Nopirin (2014), efficiency means no waste.

Achievement of efficiency is influenced by two factors including internal factors and external factors. Internal factors, which are the technical and managerial abilities of farmers in farming include land area and control, education, age, income, experience, mastery of technology, and the ability of farmers to process information to increase their production. External factors include things beyond the farmers' control, such as natural disasters, climate, prices, plant diseases and pests, and so on (Sumaryanto, 2003).

Paramitha (2014) in her research concluded that the level of technical efficiency in the use of smallholder sugarcane farming production factors (TR) is 0.84 or $84 \%$, this indicates that farmers have the opportunity to increase production by 16 percent. As for the economical result, the use of land area, medicines, and labor factors are not efficient and the fertilizer factor is inefficient and has negative value. Optimizing the use of production factors according to the recommendations that have been recommended so that sugarcane production can be increased.

Based on the research results conducted by Paramitha et al. (2014), the researchers wanted to see whether the research results were relevant to the conditions of sugarcane farming activities, especially in Purworejo Regency, which is a sugarcane producing regency with a fairly high rate of unloading ratoon (plant restoration). Farming efficiency needs to be known as a recommendation material for the sustainability of sugarcane farming in Purworejo Regency. The research was conducted after the 2017 milling season ends and before the 2018 milling season starts, which is November 2017 to March 2018.

\section{RESEARCH METHODS}

The research was conducted in Central Java Province. The research location was determined purposively in Purworejo Regency. Determination of research locations in Purworejo Regency with the consideration of a significant reduction in sugarcane area in Purworejo Regency from 657.23 in 2016 to 411.06 ha in 2017 or a decrease of 246.7 ha. The decrease in sugarcane area is because many farmers have switched commodities and therefore it is necessary to study the efficiency of sugarcane farming carried out by the farmers. The respondents are 57 people taken using the census method. The data used in this study are primary data and secondary data. To analyze the efficiency of the use of inputs in sugarcane farming activities, DEA (Data Envelopment Analysis) analysis tools are used with analysis tools DEAP Version 2.1 software. The Data Envelopment Analysis (DEA) method was created as a work evaluation tool for an activity that requires one or more types of input and produces one or more types of output. In short, the measurement is expressed by the ratio between outputs to input which a unit of measurement of efficiency or productivity 
that can be expressed partially (Cooper et al., 2006).

The basic measure of efficiency used in the DEA is the ratio of total output and total input.

$$
\text { Efficiency }=\frac{\text { Output }}{\text { Input }}
$$

The symbols in the formulation using $X$ and $\mathrm{Y}$ to represent input and output, $i$ and $j$ to represent certain inputs and outputs. Thus, $X_{1}$ is input to $i$ and $\mathrm{yj}$ is output to $j$ in the decision making unit/DMU. The sum of the inputs is represented by $I$ and the sum of the outputs is represented by $J$, where $I, J>0$. Mathematically, it can be described as follows (Ramanathan, 2003):

$$
\text { Virtual Input }=\sum_{i=1}^{I}\left(u_{i} k_{i}\right)
$$

Where $u i$ is the weight of the input of $\mathrm{xi}$ during the accumulation process. The output can be described as follows:

$$
\text { Virtual Output }=\sum_{j=1}^{J}\left(v_{j} y_{j}\right)
$$

Where $v j$ is the weight of the input of $\mathrm{yj}$ during the accumulation process. In the virtual input and output model above, efficiency can be defined as follows:

$$
\text { Efficiency }=\frac{\text { Virtual Output }}{\text { Virtual Input }}=\frac{\sum_{j=1}^{J}\left(v_{j} y_{j}\right)}{\sum_{i=1}^{I}\left(u_{i} k_{i}\right)}
$$

If there is a DMU that will be compared for the efficiency level, then the linear fraction of the DEA program is as follows:

$$
E m=\frac{\sum_{i=I}^{J}\left(v_{j m} y_{j m}\right)}{\sum_{i=I}^{J}\left(u_{\Im} k_{\mathfrak{I}}\right)}
$$

Subjec to

$$
\begin{gathered}
0 \leq \frac{\sum_{i=I}^{J}\left(v_{j m} y_{j m}\right)}{\sum_{i=I}^{J}\left(u_{\mathfrak{I}} k_{\mathfrak{I}}\right)} \leq 1 n=1,2, \ldots . N \\
v_{j m} u_{j m} \geq 0 \quad i=1,2, \ldots . I \quad j=1,2, \ldots J
\end{gathered}
$$

Where:

$E m=$ efficiency of DMU to $\mathrm{m}$

$y j m=$ output to $\mathrm{j}$ for DMU to $\mathrm{m}$.

$v j m=$ size of the output weight.

xim $=$ input to $\mathrm{i}$ for DMU to $\mathrm{m}$.

uim $=$ size of the input weight.

yjn and xin are the output to $\mathrm{j}$ and the input to $\mathrm{i}$ for the to DMU to $\mathrm{n}, \mathrm{n}=1,2, \ldots, \mathrm{N}$, respectively. And $m$ is part of $n$.

Each farmer who acts as a Decision Making Unit (DMU) has variations in the use of inputs so that the level of production also varies. The CCR model reflects (multiplication) technical efficiency and scale efficiency, while the BCC model reflects technical efficiency only, so the relative scale efficiency is the ratio of the efficiency of the CCR model and the BCC model.

$$
S=\frac{q C C R}{q B C C}
$$

If the value of $S=1$ means that the DMU operates at the best scale efficiency measure. If the $\mathrm{S}$ value is less than one, it means that there is still a scale inefficiency in the DMU. Thus, the value (1-S) shows the level of scale inefficiency of the DMU. Therefore, an efficient DMU with the CCR model means that it is also has an efficient scale. An efficient DMU with the BCC model but inefficient with the CCR model means that it has scale inefficiency.

\section{RESULTS AND DISCUSSION}

This study used 7 inputs in farming activities and 1 output. The inputs which is used to measure the efficiency of this farming are land area, phonska fertilizer, ZA fertilizer, organic fertilizers, pesticides, labor, and pest 
Table 1. Technical Efficiency and Efficiency Scale with DEA

\begin{tabular}{llccc}
\hline No & \multicolumn{1}{c}{ Efficiency Value } & TE CRS & TE VRS & SE \\
\hline 1 & Average & 0,899 & 0,937 & 0,960 \\
2 & Minimal & 0,734 & 0,767 & 0,759 \\
3 & Maximum & 1,000 & 1,000 & 1,000 \\
4 & Efficient Amount & 11 people & 21 people & 14 people \\
5 & Inefficient Amount & 46 people & 36 people & 43 people \\
\hline
\end{tabular}

Source: Processed Data, 2018

attacks. The output used is sugarcane production.

Table 1 shows that the average sugarcane farming efficiency using the assumption of Constant Return to Scale (CRS) is 0.899. This calculation resulted in 11 sugarcane farms $(19.3 \%)$ that were operating efficiently and 46 sugarcane farms $(80.7 \%)$ that were not operating efficiently (inefficient). The lowest efficiency value of 0.734 was obtained by DMU-49 and the highest value of 1,000 was achieved by 11 people. The calculation of efficiency using the assumption Variable Return to Scale (VRS) produces an average efficiency value of 0.937 . Efficiency was achieved by 21 people (36.84\%), while the remaining 36 people (63.16) still had not reached efficiency. The lowest value of 0.767 was obtained by DMU49 and the highest value of 1,000 was obtained by 21 people. Meanwhile, from the value of the Efficiency Scale (SE), 14 people have reached full efficiency, which means that the DMU has achieved efficiency both from the CRS and VRS assumptions. While, the remaining 43 people are still in the inefficiency category.

The results of DEA calculations using VRS assumptions can be seen from the observed position of return to scale (RTS) of sugarcane farming, whether in the position of increasing return to scale (IRS), constant return to scale (CRS) or decreasing return to scale (DRS).

The calculations results using the DEA method show that the RTS value which is mostly of the current sugarcane farming is in the diseconomics of scale position, it is showed with the indicator of 37 sugarcane farming $(64,91 \%)$ is in the position of decreasing (Supra-optimal) return to scale, 14 sugarcane farming is in the position of constant return to scale or optimal scale, and only 6 sugarcane farms have an increasing return to scale or sub optimal scale. The results of this analysis mean that sugarcane farming currently must reduce the number of existing inputs to achieve efficiency.

Respondents who operate on a CRS scale and have a technical efficiency value of 1.00 , this means that the proportion of additional production input is the same as the proportion of additional output. This is because the technical efficiency value obtained from the CRS assumption is the same as the VRS assumption, so the efficiency scale obtained is 1.00. Six respondents have achieved technical efficiency and operate on the IRS scale, namely a situation where the proportion of additional input will result in a larger proportion of output. Even though the

Table 2. Efficiency Scale and Return to Scale from DEA

\begin{tabular}{lccc}
\hline \multicolumn{1}{c}{ Efficiency Value } & $\begin{array}{c}\text { Number of } \\
\text { DMU (person) }\end{array}$ & Percentage (\%) & Efficiency Scale \\
\hline Total sampel & 57 & 100 & 0,960 \\
Decreasing return to scale (DRS) & 37 & 64.91 & 0,941 \\
Constant return to scale (CRS) & 14 & 24.56 & 1,000 \\
Increasing return to scale (IRS) & 6 & 10.53 & 0,984 \\
\hline
\end{tabular}

Source: Processed Data, 2018 
technical efficiency value is 1.00 , this means that respondents in the IRS category can still add to the input used because the ratio of the additional output to be received is still greater than the additional input issued. There are 37 DMUs operating at the DRS scale. DMU which is in a DRS position should not make additional use of production factors, because this addition results in a smaller proportion of additional production yields.

Inaccurate input allocation is the main cause of inefficiency in sugarcane farming. If the input used is excessive or insufficient, it will cause inefficient farmers. The combination of the accurate input is extremely important in sugarcane farming, when it reaches full efficiency, will in turn provide maximum income for farmers. There are still many farmers who are in the category of decreasing return to scale, indicating that the allocation of input use is inaccurate so that it tends to reduce yields and make sugarcane farming costs even greater, and there are approximately 6 sugarcane farms that are still in the category of increasing return to scale, meaning that by increasing the number of certain inputs, sugarcane farming can achieve full efficiency, and there are 14 sugarcane farmers who are efficient in allocating input so that they are in a constant return to scale condition. The increasing returns to scale condition of sugarcane farming in Purworejo Regency has also been explained by Febianti et al. (2015) in her research which states that from the results analysis of the allocative use of sugarcane production input by farmers in the form of land area, seeds, phonska fertilizer, cultivated labor and harvest labor have not been efficient and still needs to be added to achieve efficiency.

Farmers in the constant return to scale category must be able to maintain the use of production inputs in the form of phonska fertilizer, ZA fertilizer, organic fertilizers, pesticides, and labor because the combination of the use of these production factors is correct. Inefficient use of production factors is caused by 2 factors, namely the excess use of production factors and the lack of use of production factors in the form of phonska fertilizer, ZA fertilizer, organic fertilizers, pesticides, and labor. Farmers in the decreasing return to scale category still have the opportunity to obtain maximum results as obtained by farmers who are technically efficient by reducing the use of phonska fertilizers, ZA fertilizers, organic fertilizers, pesticides, and labor. Meanwhile, farmers in the category of increasing return to scale can achieve efficiency by increasing the use of phonska fertilizers, ZA fertilizers, organic fertilizers, pesticides, and labor. The recommended amount of reduction and addition of organic fertilizers, pesticides, and labor varies depending on the efficiency value produced.

\section{CONCLUSIONS}

Sugarcane farms in Purworejo Regency is divided into 3 categories including decreasing returns to scale, increasing returns to scale, and constant returns to scale. Decreasing return to scale condition is a condition where the use of production inputs is still excessive. Inefficiency occurs due to the use of excessive production inputs but has not yet reached the optimal output so that efficiency can be achieved by reducing the used production input.

Increasing return to scale is the opposite of decreasing return to scale where the use of production inputs in sugarcane farming activities is still lacking. Therefore, it is necessary to increase the use of production inputs such as fertilizers, pesticides, and labor to achieve farming efficiency.

Farms in the constant return to scale category are farms that have achieved efficiency. Farms which are already in this category must be able to maintain the use of production inputs in the form of phonska fertilizer, ZA fertilizer, organic fertilizer, pesticides, and labor because the combination of the use of these production factors is correct. 


\section{REFERENCES}

Asyarif, M. I. and N. Hanani. 2018. Analisis efisiensi teknis usahatani tebu lahan kering di Kabupaten Jombang. Jurnal Ekonomi Pertanian dan Agribisnis 2(2):159-167.

Statistics Indonesia. 2017. Statistik tebu Indonesia. Jakarta: Badan Pusat Statistik.

Cooper, W.W., L. M. Seiford, and K. Tone. 2006. Data envelopment analysis a comprehensive text with models, applications, references and DEASolver software second edition. United States of America: Springer Science+Business Media.

Febianti, D. I., Jamhari, and S. Hartono. 2015. Hartono. Efisieni usahatani tebu di Kabupaten Purworejo. Jurnal Agro Ekonomi 26(1): 1-10.

Fitriani, S., and L. Irawati. 2013. Faktorfaktor yang mempengaruhi produksi, curahan kerja dan konsumsi petani tebu rakyat di Provinsi Lampung. Jurnal Ilmiah ESAI 7(1): 38-48.

Nopirin. 2014. Pengantar ilmu ekonomi mikro makro. Yogyakarta: BPFE.

Paramitha, P., R. Wibowo, and A. Fajar. 2014. Studi efisiensi teknis dan ekonomis usahatani tebu sendiri dan tebu rakyat di Pabrik Gula Padjarakan. Berkala Ilmiah Pertanian 1(1): 1-13.

Ramanathan, R. 2003. An introduction to data envelopment analysis: A tool for performance measurement. New Delhi: Sage Publications Inc.

Soekartawi. 2010. Agribisnis teori dan aplikasinya. Jakarta: Rajawali Pers.

Sumaryanto. 2003. Determinan efisiensi teknis usahatani padi di lahan sawah irigasi. Jurnal Agro Ekonomi 21(1): 7296. 